\title{
Photodynamic effects of two water soluble porphyrins evaluated on human malignant melanoma cells in vitro
}

\author{
Agnieszka Szurko ${ }^{1,2}$, Gabriela Krämer-Marek ${ }^{1 凶}$, Maria Wideł $^{2}$, Alicja Ratuszna ${ }^{1}$, \\ Jan Habdas ${ }^{3}$ and Piotr Kuś ${ }^{3}$ \\ ${ }^{1}$ Institute of Physics, University of Silesia, Katowice, Poland; ${ }^{2}$ Department of Experimental \\ and Clinical Radiobiology, Center of Oncology, Gliwice, Poland; ${ }^{3}$ Institute of Chemistry, \\ University of Silesia, Katowice, Poland
}

Received: 17 May, 2003; revised: 28 September, 2003; accepted: 14 November, 2003

Key words: photodynamic therapy, synthetic porphyrins, malignant melanoma, tumour megacolonies in vitro, apoptosis, necrosis

\begin{abstract}
Two water soluble porphyrins: meso-tetra-4- $N$-methylpyridyl-porphyrin iodide $\left(\mathrm{P}_{1}\right)$ and 5,10-di-(4-acetamidophenyl)-15,20-di-(4- $N$-methylpyridyl) porphyrin $\left(\mathrm{P}_{2}\right)$ were synthesised and evaluated in respect to their photochemical and photophysical properties as well as biological activity. Cytotoxic and phototoxic effects were evaluated in human malignant melanoma Me45 line using clonogenic assay, cytological study of micronuclei, apoptosis and necrosis frequency and inhibition of growth of megacolonies. Both porphyrins were characterised by high UV and low visible light absorptions. Dark toxicity measured on the basis of the clonogenic assay and inhibition of megacolony growth area indicated that $P_{1}$ was non-toxic at concentrations up to $50 \mu \mathrm{g} / \mathrm{ml}(42.14 \mu \mathrm{M})$ and $P_{2}$ at concentrations up to $20 \mu \mathrm{g} / \mathrm{ml}(16.86 \mu \mathrm{M})$. The photodynamic effect induced by red light above $630 \mathrm{~nm}$ indicated that both porphyrins were able to inhibit growth of melanoma megacolonies at non-toxic concentrations. Cytologic examination showed that the predominant mode of cell death was necrosis.
\end{abstract}

Photodynamic therapy (PDT), involving incorporation of photosensitising molecules into tumour cells and their destruction after excitation with visible light (Oleinick \& Ev- ans, 1998) offers an alternative treatment to conventional therapies and is increasingly accepted as a therapeutic modality in oncology (Wilson et al., 1992; Nseyo et al., 1998; Lavie

\footnotetext{
${ }^{\circledR}$ Corresponding author: Gabriela Krämer-Marek, Institute of Physics, University of Silesia, Uniwersytecka 4, 40-007 Katowice, Poland; tel. (48 32) 359 1501; fax (48 32) 258 8431; e-mail: rysia1@go2.pl
}

Abbreviations: DAPI, 4',6'-diamidino-2-phenyl · $\mathrm{HCl}$; PDT, photodynamic therapy; $\mathrm{P}_{1}$, meso-tetra4- $N$-methylpyridyl-porphyrin iodide; $\mathrm{P}_{2}, 5,10$ di-(4-acetamidophenyl)-15,20 di-(4- $N$-methylpyridyl) porphyrin. 
et al., 1999; Dougherty, 2002). The most widely investigated photosensitisers in PDT are hematoporphyrin derivatives (HPD), among them Photofrin II, which has recently been approved for clinical treatment (Dougherty et al., 1998). However, its use may be limited because of weak absorbance at the shorter range of the red region of the spectrum, and induction of long lasting skin photosensitivity. Furthermore, Photofrin II is not a pure substance but a mixture of hematoporphyrin monomers, dimers, oligomers and their dehydration products. Due to these limitations chemists were challenged to replace Photofrin with other porphyrins or new agents with bioactivity suitable for use in PDT. Currently, various second-generation photosensitisers, such as chlorins, phtalocyanins and others are under investigation (Wesley et al., 2000; Drzewiecka et al., 2001; Lottner et al., 2002).

In the present study we tested the physicochemical and biological properties of two newly synthesised, water soluble porphyrins: meso-tetra-4- $N$-methylpyridyl-porphyrin iodide $\left(\mathrm{P}_{1}\right)$, and 5,10-di-(4-acetamidophenyl)-15,20-di-(4- $N$-methylpyridyl)-porphyrin $\left(\mathrm{P}_{2}\right)$. Cytotoxic and phototoxic effects were evaluated in human malignant melanoma cells using clonogenic assay, cytologic examination of micronuclei and analysis of apoptosis and necrosis frequency and inhibition of growth of megacolonies. Megacolonies introduced by Kummermehr et al. (1996) have been successfully used for investigations of radiotherapy response of recurrent clones of murine carcinoma in comparison with parent cells (Tarnawski et al., 1998). Recently this system was used for the study of tumour cell repopulation during conventional and accelerated radiotherapy (Tarnawski et al., 2003). Megacolonies, multicellular, flat structures growing attached to the bottom of culture flasks resemble in some respect tumours growing in vivo. A poorly proliferating multilayer dense core is surrounded by a monolayer rim of actively proliferating cells.
The cytotoxic and phototoxic effect on a single megacolony can be measured as inhibition of growth of the megacolony and changes of its area relative to the initial size. This paper presents results of a study of the photodynamic efficiency of two water soluble porphyrins using the megacolony system and monolayer culture.

\section{MATERIALS AND METHODS}

The porphyrins tested. The compounds studied were: meso-tetra-4- $N$-methylpyridyl-porphyrin iodide, and 5,10-di-(4-acetamidophenyl)-15,20-di-(4- $N$-methylpyridyl)-porphyrin. Both agents were synthesised by the
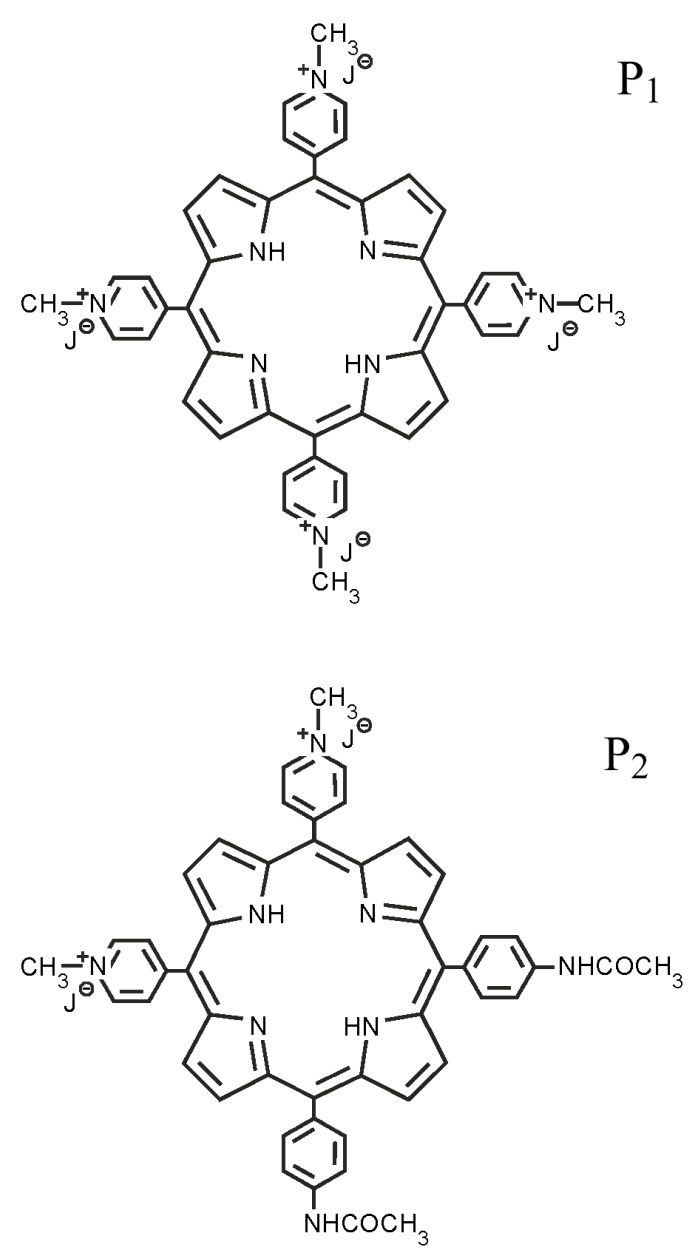

Scheme 1. Porphyrin structures.

$\mathrm{P}_{1}$, meso-tetra-4- $N$-methylpyridyl-porphyrin iodide and $\mathrm{P}_{2}$, 5,10-di-(4-acetamidophenyl)-15,20-di-(4- $N$-methylpyridyl)-porphyrin. 
Adler-Longo method involving refluxing 4-pirydyl aldehyde, or 4-acetamide benzaldehyde and 4-pirydyl aldehyde in propionic acid (Adler, Longo et al., 1967). The porphyrins were made water soluble by converting into methyl iodide salts by treatment with a mixture of methyl iodide and nitromethane (Sersuro \& Shoko, 1977; Lindsey et al., 1989).

\section{Cell line, culture and experimental} model. The cell line used throughout the study was human malignant melanoma, Me45. This line was derived from a primary culture of lymph node metastasis of skin melanoma originally located on the temple of a 35-year-old male patient and was established at the Department of Experimental and Clinical Radiobiology, Center of Oncology in 1997 (Kumala et al., 2003). Cells were routinely maintained as a monolayer culture in growth medium, DMEM (Dulbecco's Modified Eagle's Medium, Sigma-Aldrich, Germany) supplemented with $12 \%$ foetal bovine serum (Gibco BRL, Scotland) and antibiotics: 100 $\mathrm{IU} / \mathrm{ml}$ penicillin, $100 \mu \mathrm{g} / \mathrm{ml}$ streptomycin and $80 \mu \mathrm{g} / \mathrm{ml}$ gentamycin (Polfa, Poland).

To generate megacolonies, the technique described by Tarnawski et al. (2003) was used. Briefly, about $50 \mu \mathrm{l}$ of cell suspension (about $5 \times 10^{4}$ cells) was carefully placed as single drops at the bottom of flasks (5 drops per 25 $\mathrm{cm}^{2}$ flask, Nunc) and left in a humidified incubator (with $5 \% \mathrm{CO}_{2}$ ) for $24 \mathrm{~h}$ for attachment. Then the cultures were washed with serum-free medium to remove non-attached cells and $5 \mathrm{ml}$ of fresh growth medium was added. Following further 4 or 5 days of incubation the megacolonies reached diameters of about $5 \mathrm{~mm}$ and at that size were used for experiments.

Clonogenic assay of cytotoxicity. In the first step dark toxicity of the porphyrins was estimated in clonogenic cell survival assay, a method often used in PDT studies (West \& Moore, 1988). Appropriate aliquots of cells were seeded onto culture dishes (Nunc) of 5-cm diameter and left in a $\mathrm{CO}_{2}$ incubator for attachment. Eighteen hours later the medium was replaced by $5 \mathrm{ml}$ of fresh medium containing different concentrations of porphyrins $(0-100 \mu \mathrm{g} / \mathrm{ml})$ and the cells were incubated for $72 \mathrm{~h}$. Then the cells were washed, to remove any traces of porphyrins, resuspended in fresh medium and left for another 7 days to obtain macroscopically visible colonies. The colonies were fixed in ethanol and stained with $1 \%$ crystal violet. Only colonies containing at least 50 cells were counted. Surviving fractions were calculated as the ratios of plating efficiencies (number of colonies/number of cells seeded) for a given concentration of the agent to the plating efficiency of the control.

Cytotoxicity and phototoxicity assay by the megacolony system. When the megacolonies reached a diameter of about $5 \mathrm{~mm}$, the initial megacolony contour was drawn with a thin marker, copied onto transparent foil and scanned by computer scanner. The growth areas were then measured using the computer software "Image Tool".

For cytotoxicity experiments the growth medium was replaced by fresh one containing different concentrations of porphyrins $(0-100 \mu \mathrm{g} / \mathrm{ml})$. After 48 or $72 \mathrm{~h}$ the incubation medium with porphyrins was replaced by fresh complete medium and the cells were further incubated for 7-14 days. The cytotoxic effect was calculated as percent inhibition of megacolony growth at a particular porphyrin concentration in relation to the initial megacolony size.

To evaluate the photosensitising efficiency, megacolonies were incubated for 48-72 h with nontoxic (chosen on the basis of the cytotoxicity experiments) concentrations of porphyrins $\left(20 \mu \mathrm{g} / \mathrm{ml}\right.$ and $15 \mathrm{~g} / \mathrm{ml}$ for $\mathrm{P}_{1}$ and $\mathrm{P}_{2}$, respectively). Prior to irradiation the megacolonies were washed and covered with $2 \mathrm{ml}$ of ice cold phosphate buffered saline, $\mathrm{pH}$ 7.4 (PBS). Each colony was exposed to different doses of energy ranging between 13.5-81 $\mathrm{J} / \mathrm{cm}^{2}$ (irradiation time 5-30 $\mathrm{min}$ ) at room temperature $\left(21^{\circ} \mathrm{C}\right)$. Light was generated by a halogen lamp, type LH313K, equipped with a 
filter cutting off the wavelengths below 630 $\mathrm{nm}$. Following irradiation the colonies were incubated in growth medium for 7-14 days and growth areas were measured. Experiments were performed in triplicate.

Cytologic estimation of cell damage. To determine the biological effects of porphyrins on cell viability, cells were seeded into 96 -well microplates, allowed to attach for $24 \mathrm{~h}$ and then the test compounds, prepared in growth medium, were added. After further $48 \mathrm{~h}$ of incubation in a humidified $\mathrm{CO}_{2}$ incubator, the medium was replaced by serum-free medium without the compounds added and individual wells were irradiated for $20 \mathrm{~min}$. Following irradiation serum was added to the wells to reach a final concentration of $12 \%$ and the cells were further incubated for 24, 48 and $72 \mathrm{~h}$, or immediately used for analysis. Additional batch of microplates was incubated without being irradiated for the dark toxicity assessment. At a proper time, floating and attached cells (trypsinized) were combined, centrifuged and fixed in 96\% ice cold ethanol. After re-fixation in a methanol/acetic acid (3:1, $\mathrm{v} / \mathrm{v})$ mixture the cells were dropped onto microscope slides and dried overnight. Then the slides were stained with the DNA binding fluorescent dye DAPI (4', 6'-diamidino-2-phenyl . $\mathrm{HCl}$, Serva Germany) and analyzed with a fluorescent microscope (Axiophot, Zeiss, Germany) simultaneously using phase contrast to visualise the cell membrane. Intact (healthy) cells, those containing micronuclei as well as apoptotic and necrotic cells were scored according to morphologic criteria (Guo et al., 1997; Fenech et al., 1999). Healthy cells were discriminated based on their regular cell and nuclear shape and also nuclear staining weaker than in damaged cells. For examination of photodynamic properties 4000 cells were scored in total for each dose (1000 cells per slide, four slides per point prepared in two independent experiments) and the percentage of apoptotic and necrotic cells as well as cells with micronuclei were calculated.
Measurement of spectral properties. The absorbance was measured in the wavelength range of $380-700 \mathrm{~nm}$ using double-beam UV/VIS spectrophotometer Yasco V-530. For absorbance spectra analysis both porphyrins were dissolved in water in a range of concentrations.

\section{RESULTS}

Absorption spectra. Absorption spectra of both porphyrins are characterised by a Soret band in the violet region and four wide Q-bands located in the 500-650 $\mathrm{nm}$ region (Table1). The absorption coefficients of the bands were obtained from the Beer-Lambert law using $10^{-4}-10^{-6} \mathrm{M}$ solutions. They were comparable to those for similar compounds (Kwaśny \& Graczyk, 1990). No tendency to aggregate was observed. However, this does not exclude the possibility of aggregation inside cells, which is often found for such compounds. No significant difference was observed in the shape of the UV-VIS spectra of the compounds studied (not presented). Only a small difference in the peak positions was seen. This similarity may indicate that the photodynamic properties should not vary considerably from one compound to another.

The high absorbance in the Soret band and significantly lower one for the $\mathrm{Q}$ bands indicate suitability of the studied porphyrins in photodynamic therapy (PDT) and diagnosis (PDD). The longest-wave absorption bands at 642 and $648 \mathrm{~nm}$ observed for $\mathrm{P}_{1}$ and $\mathrm{P}_{2}$, respectively, are the most important ones regarding PDT, because only red light has sufficient tissue penetration ability.

\section{Porphyrin cytotoxicity}

As shown on the photograms (Fig. 1) apoptotic cells were characterised by cellular shrinkage and nuclear condensation in early stages of apoptosis and nuclear fragmentation in later ones. Necrotic cells were charac- 
Table 1. Absorption spectra for meso-tetra-4-N-methylpyridyl-porphyrin $\left(\mathrm{P}_{1}\right)$ and 5,10-di-(4-acetamidophenyl)-15,20-di-(4-N-methylpyridyl) porphyrin $\left(\mathrm{P}_{2}\right)$

\begin{tabular}{|c|c|c|c|}
\hline & & $\mathbf{P}_{1}{ }^{*}$ & $\mathbf{P}_{2}^{* *}$ \\
\hline \multirow{2}{*}{$\mathrm{Q}_{\mathrm{x}}$} & $\lambda_{\max }[\mathrm{nm}]$ & 422 & 433 \\
\hline & $\varepsilon_{0-0}\left[\frac{d m^{3}}{m o l \cdot c m}\right]$ & $3.26 \times 10^{5}$ & $3.80 \times 10^{4}$ \\
\hline \multirow{2}{*}{$\mathrm{Q}_{\mathrm{x}}$} & $\lambda_{\max }[\mathrm{nm}]$ & 518 & 523 \\
\hline & $\mathcal{E}_{1-0}\left[\frac{d m^{3}}{m o l \cdot c m}\right]$ & $2.20 \times 10^{4}$ & $6.9 \times 10^{3}$ \\
\hline \multirow{2}{*}{$Q_{y}$} & $\lambda_{\max }[\mathrm{nm}]$ & 554 & 566 \\
\hline & $\varepsilon_{0-0}\left[\frac{d m^{3}}{m o l \cdot c m}\right]$ & $8.1 \times 10^{3}$ & $5.1 \times 10^{3}$ \\
\hline \multirow{2}{*}{$Q_{y}$} & $\lambda_{\max }[\mathrm{nm}]$ & 584 & 588 \\
\hline & $\varepsilon_{1-0}\left[\frac{d m^{3}}{m o l \cdot c m}\right]$ & $9.3 \times 10^{3}$ & $4.3 \times 10^{3}$ \\
\hline \multirow{2}{*}{ B } & $\lambda_{\max }[\mathrm{nm}]$ & 648 & 642 \\
\hline & $\boldsymbol{\varepsilon}_{\mathbf{0}-0}\left[\frac{d m^{3}}{m o l \cdot c m}\right]$ & $2.5 \times 10^{3}$ & $2.8 \times 10^{3}$ \\
\hline
\end{tabular}
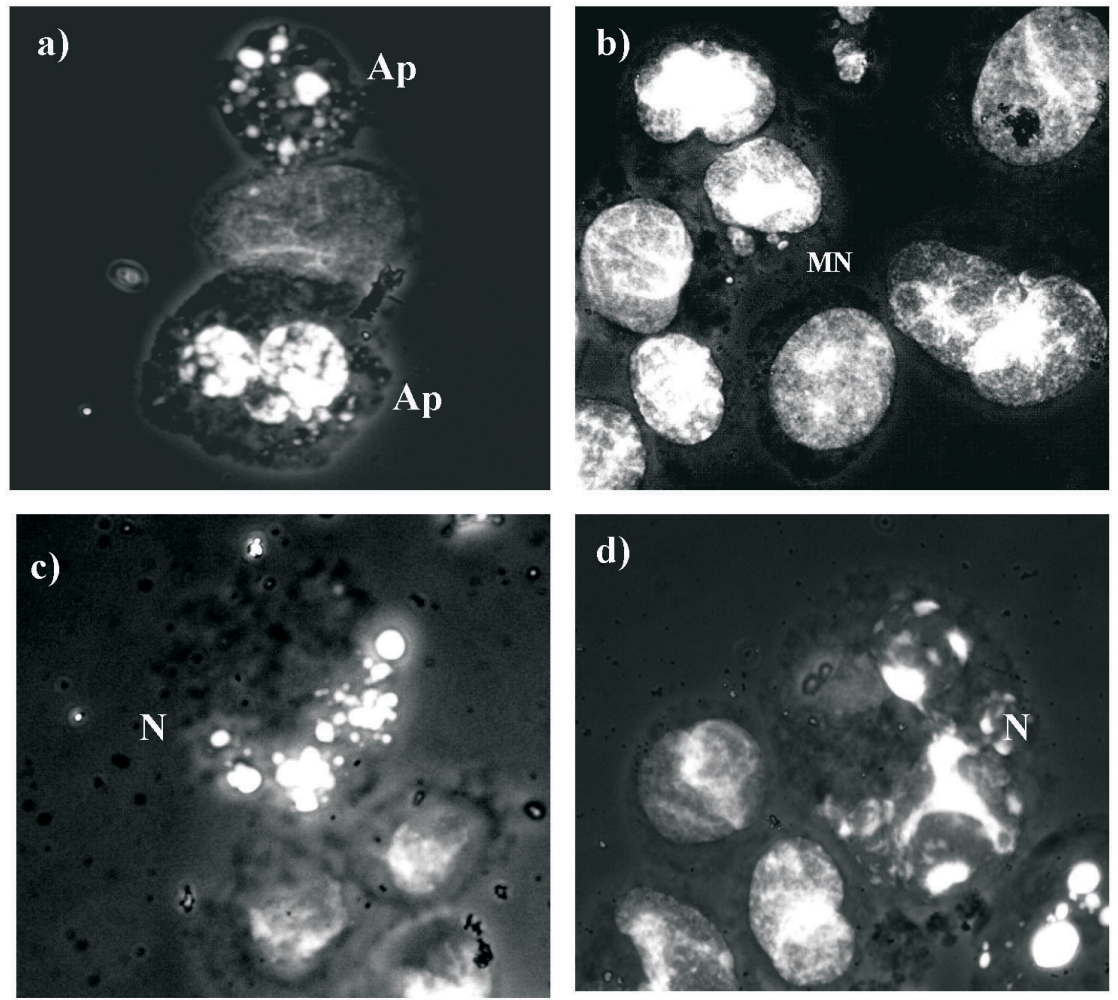

Figure 1. Pictures of apoptotic (a), necrotic (c, d) and cells with micronuclei (b) after treatment of Me45 melanoma with $P_{2}$ porphyrin and light exposure.

DAPI-stained cells observed in fluorescence and phase contrast; original magnification $400 \times$. 

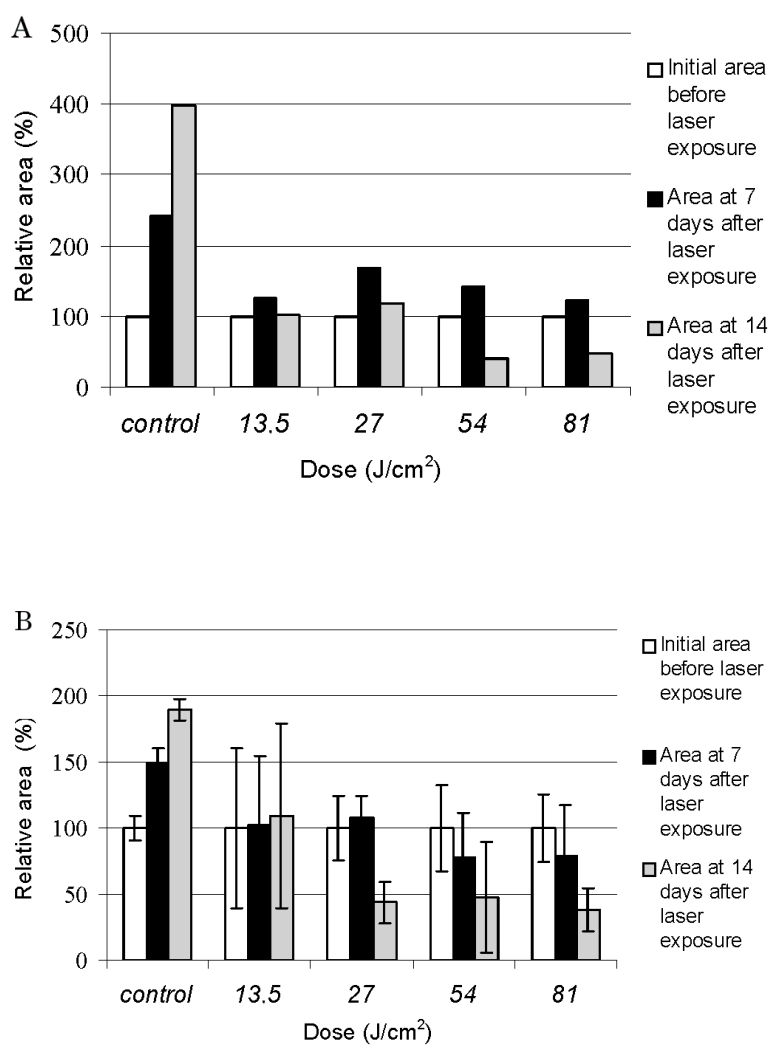

Figure 2. Reduction of areas of Me45 megacolonies after exposition to laser light and $48 \mathrm{~h}$ pre-treatment with $P_{1}$ porphyrin at $20 \mu \mathrm{g} / \mathrm{ml}$ (A), and with $\mathrm{P}_{2}$ porphyrin at $15 \mu \mathrm{g} / \mathrm{ml}$ (B).

Significant inhibition of growth of $\mathrm{P}_{1}$-treated and lighted for $20 \mathrm{~min}(P=0.034)$ and $\mathrm{P}_{2}$-treated and lighted for $10-30 \mathrm{~min}(P<0.02)$ megacolonies was observed after 14 days post-treatment incubation. One way ANOVA was used for statistical analysis.

terised by cellular swelling, plasma membrane disintegration and irregular nuclear fragmentation. On long term incubation with melanoma cells porphyrin $\mathrm{P}_{1}$ was relatively non-toxic and the surviving fraction of clonogenic cells was close to 1.0 up to the concentration of $20 \mu \mathrm{g} / \mathrm{ml}$. The surviving fraction of $\mathrm{P}_{2}$-treated clonogenic cells was unchanged up to $15 \mu \mathrm{g} / \mathrm{ml}$, but started to drop at higher concentrations, reaching the value of 0.5 at $50 \mu \mathrm{g} / \mathrm{ml}$ (not presented). Treatment of megacolonies with $0-100 \mu \mathrm{g} / \mathrm{ml}$ of the porphyrins for $48 \mathrm{~h}$ also had no significant cytotoxic influence on their growth as mea- sured by area increment. The growth area of Me45 megacolonies measured 7 day post treatment with $20 \mu \mathrm{g} / \mathrm{ml} \mathrm{P}_{1}$ increased to 150 $\pm 7 \%$ of the pre-treatment size, whereas for control it increased to $145 \pm 10 \%$ (not presented). Under the same conditions $\mathrm{P}_{2}$ was non-toxic at concentrations up to $15 \mu \mathrm{g} / \mathrm{ml}$ but at higher doses a slight, insignificant inhibition of growth areas was observed (not presented). On the basis of these data we considered the concentration of $20 \mu \mathrm{g} / \mathrm{ml}$ and 15 $\mu \mathrm{g} / \mathrm{ml}$ for $\mathrm{P}_{1}$ and $\mathrm{P}_{2}$, respectively, as nontoxic and used them for photodynamic study.

\section{Photodynamic effect}

The Me45 melanoma was sensitive to photodamage dependent on the energy applied. Growth of megacolonies was initially inhibited and later the megacolonies were partially destroyed, therefore their areas diminished. The most pronounced shrinkage of megacolonies was observed after 14 days for megacolonies treated with $\mathrm{P}_{1}$ and exposed to light for 20 and $30 \mathrm{~min}$ (Fig. 2A). A considerable megacolony shrinkage after $\mathrm{P}_{2}$ treatment was observed on the 14th day post exposition to light for 10-30 min (Fig. 2B). Control experiment showed that irradiation alone did not inhibit megacolony growth (not presented).

\section{Micronuclei, apoptosis and necrosis}

Microscopic analysis of cellular damage indicated that cell death due to necrosis was the predominant biological effect of photodynamic action of both porphyrins under study (Fig. 3A). No necrotic cells were present right after $20 \mathrm{~min}$ of irradiation, however after $24 \mathrm{~h}$ they amounted $20 \%$ and after $48 \mathrm{~h}$ they constitute $30 \%$ in the case of both compounds. At $72 \mathrm{~h}$ post irradiation the level of necrosis reached almost 40 and $45 \%$ for $\mathrm{P}_{1}$ and $\mathrm{P}_{2}$, respectively. The frequency of necrosis induced by photodynamic treatment with either agent was significantly higher as compared to the effect of irradiation alone, porphyrin alone or 

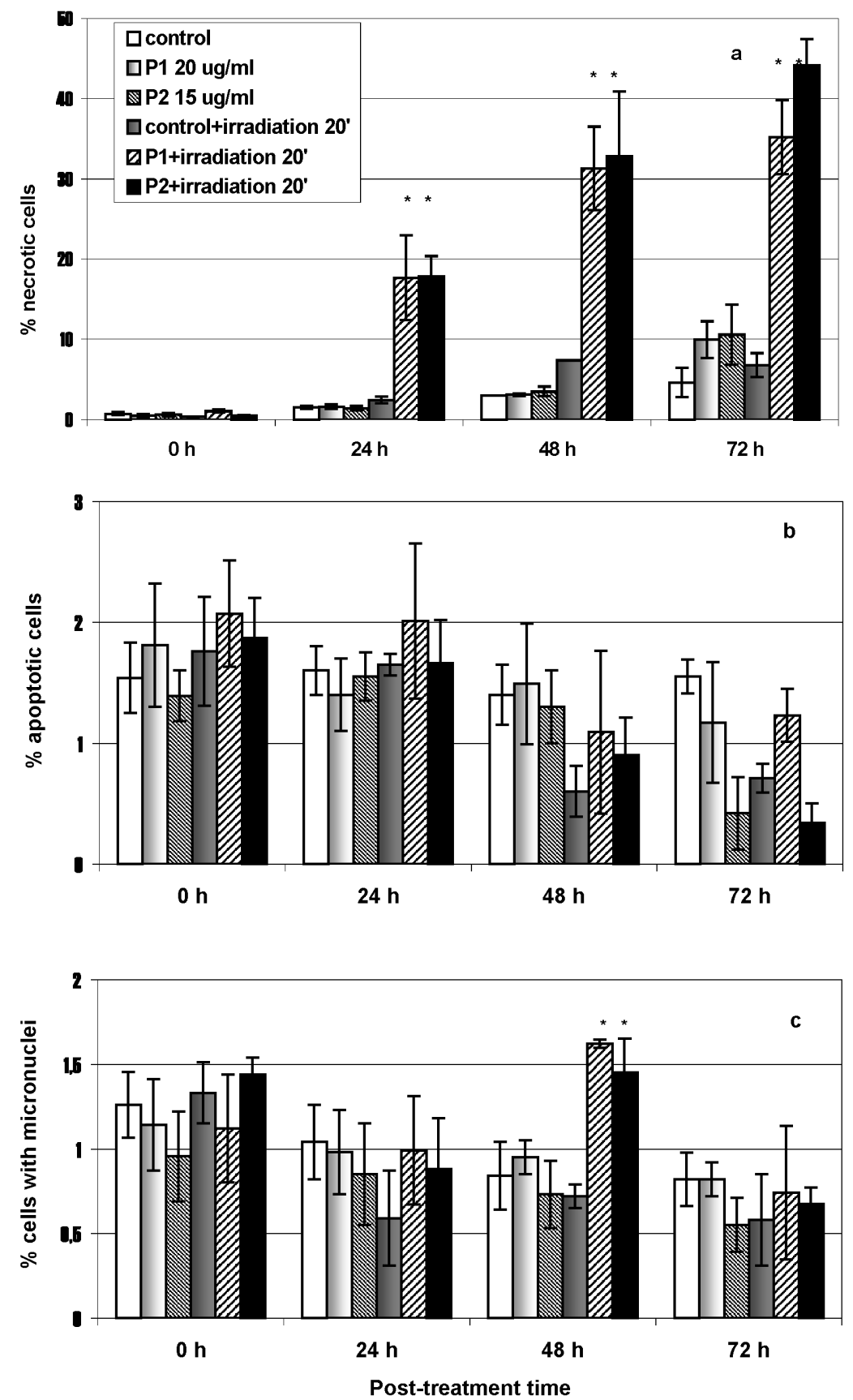

Figure 3. Morphologic study of cellular damage: micronuclei (A), apoptosis (B) and necrosis (C).

Significant difference with appropriate non-irradiated control at $P<0.05$ level indicated by asterisks.

no treatment at all $(P<0.05)$. At the same time when necrosis increased, apoptosis frequency remained unchanged $(24 \mathrm{~h})$, or was diminished in comparison with untreated control (Fig. 3B, $48 \mathrm{~h}$ and $72 \mathrm{~h}$ ). Slight but significant increase of micronuclei frequency was observed only after $48 \mathrm{~h}$ post irradiation in both groups treated with porphyrins and light (Fig. 3C).

\section{DISCUSSION}

This study is a part of a complex project aimed at synthesis of new porphyrin derivatives, their physico-chemical characterisation and evaluation of biological efficiency. The assays most frequently used in experimental PDT are cell survival assay based on colony formation (West \& Moore, 1988) or an assay 
based on cell viability, e.g. tetrazolium reduction colorimetric method (MTT assay) (Yow et $a l ., 2000)$. In our study we used a new model of tumour in vitro culture, the megacolonies. In our opinion these multicellular, flat but multilayer structures have some advantage over monolayer or cell suspension cultures since megacolonies can be observed for a long period without the necessity of passaging. The agents used in this study are chemically defined porphyrin derivatives which can be superior to Photofrin. Their red absorption bands are all at longer wavelengths than the bands of Photofrin II, but the differences are not considerable (642 nm for $\mathrm{P}_{1}$ and $648 \mathrm{P}_{2}$ compared with 627 for Photofrin). Thus, they are not expected to produce a large increase in tissue penetration by light. However, both agents exerted their photodynamic effect at non-toxic concentration towards human melanoma cells in vitro. Although the concentrations of the porphyrins used in the present work were high, they were within the range of hematoporphyrin concentrations applied by other authors (Yow et al., 2000).

We used tumour growth inhibition as a main criterion of the photodynamic activity of our compounds. In fact we observed prolonged cell death, visible both as megacolony growth inhibition or even shrinkage, and substantial cell loss from the megacolonies. However, inhibition of megacolony growth alone does not explain the nature of cellular death, apoptosis or necrosis, since either can be the way of death after PDT (Ahmad \& Mukhtar, 2000). These mechanisms can be different in different cell lines. Therefore, we wanted to investigate the exact nature of the cell death that was induced in M45 melanoma cells by our porphyrin derivatives and to this end we studied cellular damage and viability. Cell viability has been widely studied in vitro and in vivo and the morphological patterns of apoptosis and necrosis are well known. Microscopic assessment of apoptosis and necrosis is possible due to differential fluorescent staining (Foglieni et al., 2001; Jajte et al.,
2002). Combining fluorescent staining with DAPI with simultaneous observation of cells in phase contrast allows successful measurement of three types of cell damage: micronuclei, apoptosis and necrosis (Przybyszewski et al., 2002; Tarnawski et al., 2003). We applied the same technique in the present study in order to gain some insight into the nature of cell death occurring as an effect of the photodynamic action of porphyrin. As can be seen from Fig. 3 the porphyrins studied were not genotoxic in the dark when cytogenic damage, micronucleus induction was measured. However, after $48 \mathrm{~h}$ a slight but statistically significant increase of micronucleus frequency was noticed following photodynamic action of $\mathrm{P}_{1}$ and $\mathrm{P}_{2}$ (Fig. 3C). There was also no increase of apoptosis after irradiation with either porphyrin in comparison with controls (Fig. 3B). This may be an intrinsic property of the cell line used in this study, as it has been observed that Me45 line is resistant to apoptosis following ionizing irradiation and also after treatment with cytostatic drugs (Kumala et al., 2003). Furthermore, the observed necrosis can result from the relatively high concentration of porphyrins and high doses of light $\left(81 \mathrm{~J} / \mathrm{cm}^{2}\right)$. In experiments performed on HEC1-B endometrial carcinoma cells, Varriale et al. (2002) observed that hypericin, another type of photosensitizer, used with light doses ranging between 2 and $5 \mathrm{~J} / \mathrm{cm}^{2}$ induced mainly apoptosis, while above $6 \mathrm{~J} / \mathrm{cm}^{2}$ necrosis prevailed. The low efficiency of induction of DNA damage leading to micronuclei and lack of apoptosis after photodynamic action of both porphyrins and high incidence of necrosis suggest that the main targets for their photobiological activity are cellular membranes. However, elucidation of the mechanism requires further studies.

We are very grateful to Dr. J. Oszajca from the Department of Biophysics, Jagiellonian University for making available the halogen lamp. 


\section{R E F E R E N C E S}

Adler AD, Longo FR, Finarelli JD, Goldmacher J. (1967) J Org Chem.; 32: 476.

Ahmad N, Mukhtar H. (2000) Mechanism of photodynamic therapy-induced cell death. Methods Enzymol.; 319: 342-58.

Dougherty TJ. (2002) An update on photodynamic therapy applications. $J$ Clin Laser Med Surg.; 20: 3-7.

Dougherty TJ, Gomer CJ, Henderson BW, Jori G, Kessel D, Korbelik M, Moan J, Peng Q. (1998) Photodynamic therapy. J Natl Cancer Inst.; 90: 889-905.

Drzewiecka A, Urbanska K, Matuszak Z, Pineiro M, Arnaut LG, Habdas J, Ratuszna A, Stochel G. (2001) Tritolyloporphyrin dimer as a new potent hydrophobic sensitizer for photodynamic therapy of melanoma. Acta Biochim Polon.; 48: 277-82.

Fenech M, Crott J, Turner J, Brown S. (1999) Necrosis, apoptosis, cytostasis and DNA damage in human lymphocytes measured simultaneously within the cytokinesis-block micronucleus assay: Description of method and results for hydrogen peroxide. Mutagenesis.; 14: $605-12$.

Foglieni C, Meoni C, Davalli AM. (2001) Fluorescent dyes for cell viability: an application on prefixed conditions. Histochem Cell Biol.; 115: $223-9$.

Guo M, Chen Ch, Vidair Ch, Marino S, Dewey WC, Ling CC. (1997) Characterization of radiation-induced apoptosis in rodent cell lines. Radiat Res.; 147: 295-303.

Jajte J, Grzegorczyk J, Zmyslony M, Rajkowska E. (2002) Effect of $7 \mathrm{mT}$ static magnetic field and iron ions on rat lymphocytes: apoptosis, necrosis and free radical processes. Bioelectrochemistry.; 57: 107-11.

Kumala S, Niemiec P, Widel M, Hancock R, Rzeszowska-Wolny J. (2003) Apoptosis and clonogenic cell survival in three tumour cell lines exposed to gamma rays or chemical genotoxic agents. Cell Mol Biol Lett.; 8: 655-65.
Kummermehr J, Müller S, Eder P. (1996) The radiation response of murine squamous carcinoma cells treated as megacolonies in vitro. Radiation Research Society 44th Annual Meeting, Chicago, US A, pp 15-277.

Kwaśny M, Graczyk A. (1990) Hematoporphyrins as photosensitisers in photodynamic diagnosis and therapy of tumours. Wiadomości chemiczne.; 44: 148 (in Polish).

Lavie G, Kaplinsky C, Toren A. (1999) A photodynamic pathway to apoptosis and necrosis induced by dimethyltetrahydroxyhelianthrone and hypericin in leukaemic cells: possible relevance to photodynamic therapy. $\mathrm{Br} J \mathrm{Can}$ cer:; 79: 423-32.

Lindsey JS, Brown PA, Siesel DA. (1989) Visible light - harvesting in covalently-linked porphyrin-cyanine dyes. Tetrahedron.; 15: 4845-66.

Lottner C, Bart K-C, Bernhardt G, Brunner H. (2002) Hematoporphyrin-derived soluble porphyrin-platinum conjugates with combined cytotoxic and phototoxic antitumor activity. J Med Chem.; 45: 2064-78.

Nseyo UO, Detlaven J, Dougherty TJ, Potter WR, Merrill DL, Lundahl SL, Lamm DL. (1998) Photodynamic therapy (PDT) in the treatment of patients with resistant superficial bladder cancer: a long-term experience. $J$ Clin Laser Med Surg.; 16: 61-8.

Oleinick NC, Evans HH. (1998) The photobiology of photodynamic therapy: Cellular targets and mechanisms. Radiat Res.; 150: S146-S156.

Przybyszewski WM, Widel M, Palyvoda O. (2002) Lipid peroxidation, DNA damage, and cellular morphology of R1 rhabdomyosarcoma cell line irradiated in vitro by gamma-rays with different dose-rates. Teratog Carcinog Mutagen.; 22: 93-102.

Sersuro S, Shoko Y. (1977) Meso-tetrapyridylporphins and their metal complexes. Syntheses and physico-chemical properties. Chem Pharm Bull.; 25: 884-9.

Tarnawski R, Kummermehr J, Trott KR. (1998) The radiosensitivity of recurrent clones of 
an irradiated murine squamous cell carcinoma in the in vitro megacolony system. Radiother Oncol.; 46: 209-14.

Tarnawski R, Widel M, Skladowski K. (2003) Tumor cell repopulation during conventional and accelerated radiotherapy in the in vitro megacolony culture. Int $J$ Radiat Oncol Biol Phys.; 55: 1074-81.

Varriale L, Coppola E, Veneziani BM, Palumbo G. (2002) Molecular aspects of photodynamic therapy: low energy pre-sensitization of hypericin-loaded human endometrial carcinoma cells enhances phototolerance, alters gene expression and affects the cell cycle. FEBS Lett.; 152: 287-90.

Wesley MS, Allen CM, Van Lier JE. (2000) Role of activated oxygen species in photodynamic therapy. Methods Enzymol.; 319: 342-58.
West CML, Moore JV. (1988) Cell survival characteristics of human colon adenocarcinoma cell line after photodynamic treatment: a comparison of Photofrin II and TPPS. Int $J$ Radiat Biol.; 54: 621-34.

Wilson BD, Mang TS, Stoll H, Jones C, Cooper M, Dougherty TJ. (1992) Photodynamic therapy for the treatment of basal cell carcinoma. Arch Dermatol.; 128: 1597-601.

Yow CMN, Chen JY, Mak NK, Cheung NH, Leung AWN. (2000) Cellular uptake, subcellular localization and photodamaging effect of Temoporfin (mTHPC) in nasopharyngeal carcinoma cells: comparison with hematoporphyrin derivative. Cancer Lett.; 157: 123-31. 